\author{
Volume 4 - Nomor 1 • Oktober 2020 \\ Pege (Hal.) : 13 - 32
}

(C) Universitas Pamulang

JL.Surya Kencana No.1 Pamulang, Tangerang Selatan - Banten

Telp. (021) 7412566, Fax (021) 7412491

website. :

http://www.openjournal.unpam.ac.id/index.php/JPK

\title{
Pengaruh Digital Loyalty Program Terhadap Kepuasan Dan Loyalitas Pelanggan Studi Kasus Tokopedia
}

\author{
Devi Tri Asmarasari ${ }^{1}$, Riska Dewi Muftian ${ }^{2}$, Teguh Diyanto ${ }^{3}$, Wisnu Sakti Dewobroto ${ }^{4}$, \\ Universitas Bina Nusantara ${ }^{1,2,3}$,Universitas Agung Podomoro ${ }^{4}$ \\ devitri.indonesia@gmail.com, riskadewi612@gmail.com , teguhdiyanto123@gmail.com , \\ wisnu.dewobroto@podomorouniversity.ac.id
}

\begin{abstract}
Abstrak Dalam bisnis digital seperti marketplace, pengaruh dari program loyalitas terhadap kepuasan pelanggan belum dieksplorasi dengan baik karena bentuknya yang tidak berwujud dan tidak berhubungan secara langsung dengan pelanggan. Pengaruh dari program loyalitas terhadap loyalitas serta kepuasan pelanggan dalam e-commerce digital di Indonesia menjadi tujuan dari penelitian ini. Tokopedia memiliki beberapa program loyalitas digital di antaranya adalah Toko Points, Toko Loyalty, e-coupon, e-newsletter, dan flash sale. Penelitian ini akan menggunakan survei dengan metode distribusi online kepada pelanggan Tokopedia, dengan jumlah sampel 384 responden. Analisis regresi linier berganda digunakan untuk menguji variabel Digital Loyalty Program $(X)$ terhadap variabel kepuasan Pelanggan $(M)$ sebagai mediasi dan variabel Loyalitas Pelanggan (Y). Hasil penelitian ini menyatakan bahwa variabel Digital Loyalty Program (bersama dengan seluruh program loyalitas Tokopedia) mempengaruhi kesetiaan pelanggan serta kepuasan pelanggan Tokopedia. Variabel kepuasan pelanggan pada penelitian ini juga berperan menjadi mediasi yang menjelaskan bahwa variabel Digital Loyalty Program secara tidak langsung mempengaruhi variabel Loyalitas Pelanggan melalui Kepuasan Pelanggan Tokopedia.
\end{abstract}

Kata Kunci : Kepuasan Pelanggan; Loyalitas Pelanggan; Program Loyalitas Digital

Abstract In digital business such as marketplaces, the effect of loyalty programs on customer satisfaction has not been explored properly because of their intangible forms and not directly in touch with their customers. This research is conducted to understand the effect of loyalty program on the satisfaction and also the loyalty of customers in digital e-commerce in Indonesia. Tokopedia have several digital loyalty programs, among which are Toko Points, Toko Loyalty, e-coupon, e-newsletter, and flash sale. This research will utilize survey with an online distribution method to Tokopedia's customers, with a sample size of 384 respondents. This research will use multiple linear regression analysis to test Digital Loyalty Program $(X)$ variable on Customer Satisfaction (M) variable as a mediation and Customer Loyalty $(Y)$ variable. The result of this research states that Digital Loyalty Program variable (along with the entire Tokopedia Loyalty Program) affects Tokopedia's Customer Satisfaction and Customer Loyalty. Customer satisfaction variable in this research also plays a role as a mediating variable which explains that Digital Loyalty Program variable indirectly affects Customer Loyalty variable through Tokopedia Customer Satisfaction.

Keywords : Customer Loyalty; Customer Satisfaction; Digital Loyalty Program 


\section{A. PENDAHULUAN}

Perkembangan teknologi digital di Indonesia mengalami perkembangan yang sangat pesat dan tidak sedikit aspek bisnis sekarang mulai beralih ke versi digital, seperti salah satunya marketplace dan e-commerce yang sedang berkembang dengan cepat. Kehadiran industri ini menjadi suatu pendorong pertumbuhan ekonomi kreatif di Republik Indonesia. Sektor perdagangan elektronik di Indonesia sendiri mengalami persaingan yang sangat ketat dimana beberapa perusahaan e-commerce menawarkan model bisnis yang hampir sama satu dengan lainnya. Loyalty program berbasis digital gencar diterapkan oleh e-commerce untuk mendorong kepuasan pelanggan dan mencegah berpalingnya pelanggan ke competitor. Kepuasan pelanggan telah ditemukan menjadi penentu utama dalam membangun dan memelihara lingkungan bisnis utama (Ganiyu, 2017). Loyalty program mendorong pembeli untuk kembali ke perusahaan atau tempat mereka sering melakukan pembelian. Beberapa insentif mungkin termasuk akses lanjutan ke produk baru, diskon tambahan atau kadang-kadang barang gratis. Pelanggan biasanya mendaftarkan informasi pribadi mereka ke perusahaan dan diberi pengenal unik, seperti ID numerik atau kartu keanggotaan, dan menggunakan pengenal itu ketika melakukan pembelian.

Tokopedia satu dari sejumlah perusahaan perdagangan elektronik (e-commerce) yang berbasis digital dengan kesuksesan yang tinggi di Indonesia, dilihat dari nilai valuasi saat ini mencapai \$7 Billion USD atau sekitar Rp.102 Triliun. Tokopedia menjadi platform perdagangan elektronik dengan tingkat kunjungan terbanyak ke-tiga di Asia Tenggara, walau hanya tersedia di Indonesia, dengan 125 juta rerata pengunjung di tahun 2018. Tokopedia memiliki beberapa program loyalitas pelanggan berbasis digital untuk menjaga loyalitas pelanggannya. Dan bisa jadi program loyalitas ini merupakan salah satu faktor kesuksesan Tokopedia dalam bisnis e-commerce ini. Ketika program hadiah diintegrasikan ke dalam rutinitas sehari-hari pelanggan, program ini dapat menumbuhkan loyalitas terhadap suatu merek atau branding yang akan berpengaruh terhadap pembelanjaan kembali di Tokopedia. Loyalty program menambahkan nilai kepada perusahaan dalam hal ini Tokopedia, bagaimana Tokopedia dapat mempertahankan pelanggan melalui penawaran interaktif. Fitur-fitur yang ada pada aplikasi Tokopedia beroperasi seperti halnya program hadiah lainnya, di mana pelanggan mendapatkan poin untuk digunakan untuk pembelian kupon seperti cashback, gratis ongkos kirim dan lain sebagainya.

Digital loyalty program yang dilakukan oleh Tokopedia seperti Toko Points yang dapat ditukarkan dengan e-coupon yang bisa digunakan untuk berbagai keperluan seperti cashback, gratis ongkos kirim, dan discount lainnya. Kemudian ada Toko Loyalty yang diperoleh pengguna Tokopedia setiap melakukan proses transaksi yang berguna untuk meningkatkan status Membership untuk mendapatkan lebih banyak keuntungan, status Membership pada Tokopedia sendiri dibagi menjadi 3 bagian (silver, gold, dan platinum) yang setiap jenisnya memiliki keuntungannya masingmasing, semakin tinggi membership yang dimiliki semakin banyak keuntungan yang diperoleh. Yang ketiga berupa E-coupon yang didapatkan oleh pengguna Tokopedia melalui penukaran points dan juga melalui "lucky egg" berupa hadiah undian yang diberikan kepada pengguna pada waktu dan promosi tertentu. Selain itu, untuk memberikan informasi mengenai promosi yang sedang berlaku Tokopedia memiliki $E$ - 
Newsletter yang merupakan "magazine" versi digital yang dikirimkan kepada pengguna Tokopedia melalui e-mail yang terdaftar. Tokopedia juga sering mengadakan event dalam durasi waktu tertentu, dimana barang-barang akan dijual dengan potongan harga yang besar. Biasanya barang yang ditawarkan jumlah dan jenisnya terbatas, jadi pelanggan harus bersiap-siap untuk mengikuti event ini agar tidak kehabisan barang yang diinginkan, program ini dinamakan Flash Sale.

Beberapa penelitian membahas tentang pengaruh loyalty program terhadap kepuasan pelanggan dan loyalitas pelanggan. Terdapat beberapa perbedaan antara program konvensional dengan program berbasis digital, salah satunya adalah biasanya loyalitas pelanggan program digital lebih mengutamakan potongan harga atau cashback dibandingkan dengan memberikan suatu hadiah fisik. Selain itu interaksi antara program digital pun berbeda karena mengandalkan media e-mail, aplikasi, atau web-based dibandingkan bentuk fisik. Untuk program loyalitas pelanggan konvensional sendiri, terdapat beberapa penelitian mengenai pengaruh dari loyalty program suatu perusahaan terhadap kepuasan pelanggan yang berujung pada terciptanya loyalitas pelanggan. Salah satu sumber literatur yang ditulis oleh Abba, Douglas, dan Loyd (2015) menunjukkan bahwa loyalty program memiliki efek atau pengaruh yang lemah terhadap perilaku pelanggan yang memiliki kepuasan terhadap loyalty program tersebut pada sektor telekomunikasi di Botswana. Penelitian ini menyimpulkan bahwa perusahaan tersebut harus meningkatkan dan membedakan loyalty program dengan program promosi lainnya. Banyak pelanggan yang tidak menyadari adanya loyalty program dikarenakan terlalu banyak program promosi lainnya sehingga membuat pelanggan bingung dan cenderung untuk mengabaikannya. Namun banyak juga penelitian terkait loyalty program yang mendapatkan hasil yang baik dan berpengaruh secara signifikan terhadap kesetiaan pelanggan serta kepuasan pelanggan. Satu diantaranya adalah riset yang dilakukan Patrick dan Vesna (2009), yang menyatakan bahwa kesetiaan pelanggan dipengaruhi secara signifikan oleh loyalty program, melalui mediasi kepuasan pelanggan ritel DIY. Riset oleh Patrick dan Vesna tersebut menyimpulkan bahwa dalam lingkungan layanan ritel, tingkat kualitas interaksi pribadi dan loyalty program memiliki dampak positif pada tingkat loyalitas pelanggan melalui variabel mediasi kepuasan pelanggan. Dampak langsung dari loyalty program pelanggan pada loyalitas pelanggan juga dapat dikonfirmasi. Secara keseluruhan, konsep kepuasan pelanggan memiliki peran penting dalam memediasi kesetiaan pelanggan. Penelitian lain yang ditulis oleh Daniel et al (2018) menyatakan bahwa manfaat dari loyalty program dan kepuasan pelanggan secara signifikan mempengaruhi kesetiaan pelanggan pada industri perhotelan. Riset termaksud memperlihatkan bahwa manfaat dari loyalty program adalah target potensial untuk intervensi di antara pelanggan hotel berbintang. Penelitian ini menyebutkan bahwa meningkatkan tingkat kepuasan anggota loyalty program dapat meningkatkan retensi dan keinginan membeli kembali yang berujung pada loyalitas pelanggan. Dapat ditegaskan hubungan langsung antara manfaat loyalty program dan loyalitas pelanggan, efeknya meningkat atau menjadi lebih kuat ketika kepuasan pelanggan memediasi hubungan kedua variabel tersebut. Hasil penelitian lain yang ditulis oleh Ibrahim et al (2014) dengan objek penelitian industri ritel juga menunjukkan bahwa beberapa loyalty program seperti rebate gift vouchers, member's day, dan magazine tidak memiliki pengaruh yang berarti atas kepuasan pelanggan. Peristiwa tersebut diduga disebabkan oleh poin yang harus dikumpulkan untuk melakukan redeem terhadap gift vouchers terlalu besar dibandingkan dengan jumlah uang yang harus Jurnal Pemasaran Kompetitif, Vol. 4, No. 1 Oktober 2020 
dihabiskan oleh pelanggan, sehingga membuat pelanggan enggan untuk mengikuti program rebate gift vouchers tersebut. Lalu loyalty program lainnya seperti gift redemption dan insurance coverage juga tidak memiliki pengaruh yang berarti terhadap loyalitas pelanggan. Peristiwa tersebut diduga disebabkan adanya beberapa perusahaan lain yang memiliki program serupa dengan syarat yang lebih mudah.

Berdasarkan diskusi di atas, ada cukup bukti bahwa topik pengaruh digital loyalty program terhadap satisfaction dan loyalty pelanggan masih jauh dari tuntas. Beberapa penelitian sebelumnya melakukan penelitian terhadap pengaruh loyalty program atas kesetiaan pelanggan serta kepuasan pelanggan, dan hasil dari sejumlah penelitian termaksud juga beragam. Ada yang menghasilkan pengaruh signifikan dan ada juga yang memperlihatkan ketiadaan pengaruh yang berarti. Pada penelitian yang dilakukan oleh Ibrahim et al (2014) membahas setiap program secara rinci bagaimana pengaruhnya antara setiap loyalty program yang dimiliki terhadap kepuasan pelanggan dan loyalitas pelanggan. Maka peneliti tertarik untuk melakukan penelitian dengan topik yang sama namun penerapan loyalty program berbasis digital pada salah satu perusahaan e-commerce di Indonesia yaitu Tokopedia. Bagaimana pengaruh Digital Loyalty Program yang dilakukan oleh Tokopedia terhadap kepuasan pelanggan dan loyalitas pelanggan dan loyalty program mana yang memberikan pengaruh yang paling besar bagi kesetiaan pelanggan serta kepuasan pelanggan, dan apakah kepuasan pelanggan memiliki peran mediasi antara digital loyalty program terhadap loyalitas pelanggan. Berdasarkan uraian rumusan masalah yang sudah disampaikan di atas, berikut merupakan pertanyaan penelitian yang hendak dicari jawabannya dalam penelitian ini:

1. Apakah Digital Loyalty Program memiliki pengaruh terhadap Kepuasan pelanggan di Tokopedia?

2. Apakah Digital Loyalty Program memiliki pengaruh terhadap Kesetiaan pelanggan di Tokopedia?

3. Apakah Digital Loyalty Program berepengaruh terhadap Kesetiaan pelanggan dimediasi oleh Kepuasan pelanggan Tokopedia?

Adapun sasaran penelitian yang perlu dicapai pada penelitian ini adalah:

1. Mencari tahu sebesar apa pengaruh Digital Loyalty Program atas Kepuasan pelanggan di Tokopedia.

2. Mencari tahu sebesar apa pengaruh Digital Loyalty Program atas Loyalitas pelanggan di Tokopedia.

3. Mencari tahu peran mediasi Kepuasan pelanggan dalam pengaruh Digital Loyalty Program atas Kesetiaan pelanggan. 


\section{B. KAJIAN LITERATUR}

\section{B.1. Kepuasan Pelanggan}

Kepuasan pelanggan merupakan penilaian atau evaluasi mengenai kinerja suatu produk atau jasa apakah sesuai dengan keinginan dari pelanggan serta kecocokkan barang atau jasa tersebut dengan tujuan penggunaan produknya (Tjiptono\&Chandra, 2016), (Swastha\&Irawan, 2012). Hal ini juga dapat dikaitkan dengan seberapa besar kinerja produk tersebut sesuai dengan harapan dari pelanggan (Kotler and Amstrong, 2014).

Dari definisi diatas, dapat dinyatakan bahwa kepuasan pelanggan merupakan situasi ketika timbulnya perasaan puas pada pelanggan saat kebutuhannya terpenuhi, mendapatkan value dari produk atau jasa tersebut dan sesuai dengan harapan. Kepuasan pelanggan merupakan sikap atau feedback dari pelanggan terhadap suatu barang atau jasa yang mereka dapatkan. Penelitian ini hendak menguji apakah kepuasan pelanggan dipengaruhi oleh digital loyalty program.

Berikut beberapa indikator dari kepuasan pelanggan menurut Swastha\&Irawan (2012) terdiri dari (a) Kemudahan: jika suatu produk mudah digunakan dan nyaman maka penggan akan merasa puas. (b) Kualitas Produk: jika produk yang dibeli pelanggan berkualitas sangat baik dan sesuai dengan ekspektasinya. (c) Harga: Bagi pelanggan yang sensitive terhadap harga biasanya akan merasa puas jika harga yang ditawarkan murah, namun komponen harga tidak terlalu penting bagi pelanggan yang memiliki tingkat sensitifitas yang rendah terhadap harga. Pelanggan akan merasa puas jika harga yang ditawarkan sesuai dengan apa yang mereka dapatkan dan harapkan. (d) Service Quality: pelayanan yang memuaskan adalah pelayanan yang prima dan sesuai dengan ekspektasi pelanggan. (e) Faktor emosi: Pelanggan akan merasa bangga bila menggunakan produk dari merek tertentu.

\section{B.2. Loyalitas Pelanggan}

Loyalitas pelanggan terjadi saat pelanggan setia menggunakan produk dari merek tertentu secara terus menerus (Swastha\&Irawan, 2012). Hal tersebut dapat berlaku perilaku pembelian ulang terhadap merek tertentu secara berulang kali (Tjiptono, 2016). Menurut Kotler \& Keller (2016) loyalitas pelanggan adalah kondisi di mana pelanggan memiliki komitmen terhadap suatu merek tertentu. Penelitian ini hendak menguji apakah loyalitas pelanggan dipengaruhi oleh digital loyalty program baik secara langsung maupun tidak langsung.

Berikut beberapa indikator dari pelanggan yang loyal menurut Kotler\&Keller (2016) antara lain; (a)Pembelian Berulang Artinya pembelian suatu produk yang lebih dari saty kali oleh pelanggan yang sama. Pembelian dilakukan atas seluruh barang atau jasa yang ditawarkan yang juga mereka butuhkan. Saat pelanggan memiliki hubungan yang kuat dan berlangsung lama dengan merek tertentu maka akan terjadi pembelian secara teratur. Oleh sebab itu, produk pesaing tidak lagi memengaruhi mereka. (b)Refferal Artinya mereka memengaruhi lingkungan mereka untuk membeli barang atau jasa perusahaan kepada siapa mereka setia, sehingga dapat dikatakan bahwa mereka telah memasarkan produk dan membawa pelanggan ke perusahaan, 
untuk perusahaan. (c) Retention Artinya daya tahan melawan dampak negatif seputar perusahaan, dan tidak gampang dipengaruhi oleh daya tarik persaingan produk atau jasa serupa. (d) Membeli antarlini jasa atau produk Artinya mereka membeli produk yang sama lebih dari satu kali, atau melakukan pembelian dua jenis produk yang tidak sama dari satu perusahaan atau merek pada dua waktu berbeda.

\section{B.3. Loyalty Program}

Penelitian mengenai loyalty program sudah dimulai sejak tahun 1990-an dimana mulai banyak perusahaan yang berfokus pada retensi pelanggan (Tahal 2014). Definisi dari sebuah loyalty program dapat diartikan sebagai sebuah marketing program dengan tujuan untuk meningkatkan kepuasan dan loyalitas pelanggan dengan menawarkan hadiah sejenisnya, untuk mencapai pengembalian finansial seperti market share, posisi kompetitif, atau pembelian yang berulang. Dimana dalam waktu yang sama mengumpulkkan data pelanggan untuk melakukan marketing yang tertarget. (Bolton, 2000) (Meyer-Warden, 2008) (Breugelmans, 2014).

Francis Buttle (2004) berpendapat bahwa program loyalitas dikatakan berhasil jika program tersebut dapat menawarkan lima jenis customer value yaitu Nilai Uang (X1), berupa rewards yang dapat dinilai dengan uang. Nilai Penebusan (X2), berupa jumlah rewards yang ditawarkan. Nilai Aspirasional (X3), berupa keinginan pelanggan untuk mendapatkan rewards tersebut. Nilai Relevansi (X4), berupa tingkat kesulitas dalam mendapatkan rewards tersebut. Nilai Kenyamanan (X5) adalah tingkat kemudahan dalam mengumpulkan dan menukarkan rewards tersebut.

Dari definisi diatas dan penjelasan mengenai kepuasan dan loyalitas pelanggan, penelitian ini mengambil loyalty program sebagai independent variable yang akan diuji pengaruhnya terhadap kepuasan dan loyalitas komsumen sebagai dependent variable. Beberapa penelitian sebelumnya menunjukan bahwa loyalty program memiliki efek positif terhadap kepuasan pelanggan, loyalitas pelanggan, peningkatan brand awareness, penjualan berulang, dan peningkatan turnover. Loyalty Program juga dapat memperkuat hubungan customer dengan perusahaan terkait (Leenheer, 2007), (Parahoo, 2013), (Tahal, 2014), (Julian, 2016).

\section{B.4. Digital Loyalty Program}

Perilaku dari pengguna internet dapat berbeda jauh dengan populasi pada umumnya. Hal ini berlaku juga pada pelaku e-commerce dan efeknya terhadap sebuah Digital Loyalty Program. Loyalty program untuk sebuah bisnis digital juga biasanya berbasis digital dimana perusahaan dapat sekaligus membangun sebuah database digital untuk e-mail marketing, melacak ulang tahun customer dan eventevent special lainnya (Kooser, 2009).

Beberapa tipe loyalty program conventional dan digital telah dirangkum dalam tabel 1 sebagai berikut: 
Tabel 1. Loyalty Program Conventional vs Digital Loyalty Program

\begin{tabular}{ccc}
\hline No & $\begin{array}{c}\text { Loyalty Program Conventional } \\
\text { (Sima Ghaleb, 2015) }\end{array}$ & $\begin{array}{c}\text { Loyalty Program Digital } \\
\text { (Various source) }\end{array}$ \\
\hline $\mathbf{1}$ & Points system & Digital Point Program \\
$\mathbf{2}$ & Tier system & Digital Tier program \\
$\mathbf{3}$ & VIP memberships \\
$\mathbf{4}$ & Payback money for loyal customer & Digital payback system \\
$\mathbf{5}$ & Partnerships with other company to & Partnership program \\
provide all-inclusive offers & \\
$\mathbf{6}$ & Loyalty Card Program & Social Media Based program \\
$\mathbf{7}$ & Frequent Buyer Program & Gamification program \\
$\mathbf{8}$ & Gift Card or Certificate & Community program \\
$\mathbf{9}$ & Return policy for loyal customer & Subscription program \\
$\mathbf{1 0}$ & Discount over time or volume of & Charity Program \\
& good & Flash Sale \\
$\mathbf{1 1}$ & Bundled Goods &
\end{tabular}

Beberapa penelitian mengenai Digital Loyalty Program memiliki hasil yang beragam terhadap kepuasan pelanggan dan loyalty. Penelitian oleh Helena et al.,, menunjukkan digital loyalty program terbukti meningkatkan penjualan, tapi tidak menghasilkan loyalitas yang sesungguhnya (true loyalty) terhadap perusahaan (Helena, 2018). Penelitian oleh Tahal et al., juga menunjukan bahwa 73\% pengguna e-commerce mengaku senang terhadap program-program loyalty, tapi dalam kenyataannya hanya 31\% dari pengguna yang mengaku mengikuti program loyalty tersebut (Tahal,2014). Hal ini menimbulkan sebuah pertanyaan, apakah Digital Loyalty Program memiliki efek yang positif terhadap kepuasan pelanggan dan loyalitas pelanggan. Penelitian yang sama juga menunjukkan bahwa ada ada ketidakcocokan antara loyalty program yang dikomunikasikan oleh perusahaan dibandingkan dengan loyalty program yang disebenarnya diharapkan oleh pelanggan (Tahal, 2014). Hal ini mengakibatkan loyalty program menjadi tidak tepat sasaran dan tidak mencapai tujuan yang diharapkan.

\section{B.5. Kerangka Konseptual}

Variabel independent dalam penelitian ini adalah Digital Loyalty Program (X) sedangkan variabel dependent yang ingin diteliti dalam penelitian ini adalah loyalitas pelanggan $(\mathrm{Y})$, dan kepuasan pelanggan $(\mathrm{M})$ dalam penelitian ini sebagai variabel mediasi. Ada 5 Digital Loyalty Program dari Tokopedia yang akan dipelajari dalam penelitian ini: Toko Points, Toko Loyalty, E-kupon, E-Newsletter, dan Flash Sale. Lima program ini akan dipakai untuk meneliti pengaruh dari Digital Loyalty Program yang diterapkan oleh Tokopedia terhadap kepuasan dan loyalitas pelanggan. 


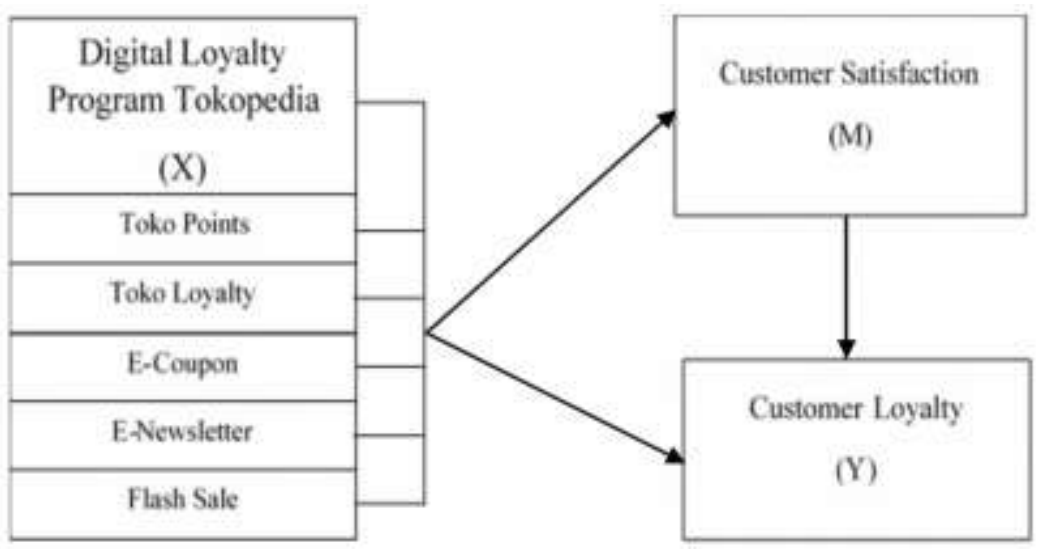

Sumber: Peneliti (2019)

Gambar 1. Kerangka Konseptual

\section{B.6. Pengembangan Hipotesis}

Penelitian ini akan berfokus pada apakah Digital Loyalty Program memiliki keterlibatan yang baik terhadap pelanggannya. Apakah sebuah Digital Loyalty Program memiliki pengaruh yang signifikan terhadap kepuasan pelanggan dan loyalitas pelanggan. Berdasarkan penelitian sebelumnya yang telah dibahas pada tinjauan pustaka, hipotesis yang dapat terbentuk adalah :

H1 : Digital Loyalty Program berpengaruh secara signifikan terhadap kepuasan pelanggan.

H2 : Digital Loyalty Program berpengaruh secara signifikan terhadap loyalitas pelanggan.

Dengan bantuan teknologi, beberapa tipe loyalty program baru bisa ditawarkan kepada pelanggan seperti yang telah dijabarkan pada tabel 1 diatas, seperti sistem Gamification yang menawarkan loyalty program seperti bermain video game. Selain itu ada pula loyalty program berbasis social media seperti fan page dan community forum. Walaupun demikian, beberapa sistem loyalty program yang terbukti populer tetap dipakai seperti point program, tier program, membership program, dan payback program, dan flash sale program. Kelima tipe loyalty program ini merupakan program yang paling sering dipakai oleh digital business seperti Tokopedia yang menjadi jenis loyalty program pada penelitian ini. Berdasarkan pengembangan loyalty program menjadi versi digital, peneliti ingin mengajukan hipotesis bahwa kelima loyalty program berbasis digital dari Tokopedia tersebut masing-masing memiliki pengaruh yang signifikan terhadap kepuasan dan loyalitas pelanggan :

H1a : Toko Points program berpengaruh secara signifikan terhadap kepuasan pelanggan.

$\mathrm{H} 1 \mathrm{~b}$ : Toko Loyalty program berpengaruh secara signifikan terhadap kepuasan pelanggan.

H1c : E-coupon program berpengaruh secara signifikan terhadap kepuasan pelanggan. $\mathrm{H} 1 \mathrm{~d}$ : E-newsletter program berpengaruh secara signifikan terhadap kepuasan pelanggan. 
H1e : Flash Sale program berpengaruh secara signifikan terhadap kepuasan pelanggan.

$\mathrm{H} 2 \mathrm{a}$ : Toko Points program berpengaruh secara signifikan terhadap loyalitas pelanggan.

$\mathrm{H} 2 \mathrm{~b}$ : Toko Loyalty program berpengaruh secara signifikan terhadap loyalitas pelanggan.

H2c : E-coupon program berpengaruh secara signifikan terhadap loyalitas pelanggan.

$\mathrm{H} 2 \mathrm{~d}$ : E-newsletter program berpengaruh secara signifikan terhadap loyalitas pelanggan.

$\mathrm{H} 2 \mathrm{e}$ : Flash Sale program berpengaruh secara signifikan terhadap loyalitas pelanggan

Menurut Iddrisua et al (2015) dalam penelitiannya menyatakan bahwa kepuasan pelanggan dan loyalitas pelanggan memiliki pengaruh secara langsung berdasarkan nilai korelasi sebesar 0.763 antar variabel tersebut. Berdasarkan pada penelitian-penelitian sebelumnya, penelitian ini akan berfokus pada bagaimana pengaruh dari Digital Loyalty Program terhadap kepuasan pelanggan dan loyalitas pelanggan. Oleh karena itu dapat terbentuk hipotesis ketiga dan kempat sebagai berikut :

H3 : Kepuasan pelanggan berpengaruh secara signifikan terhadap loyalitas pelanggan. H4 : Kepuasan pelanggan memiliki peran mediasi antara digital loyalty program dengan loyalitas pelanggan.

\section{METODE PENELITIAN}

Metode kuesioner digunakan dalam penelitian ini sebagai metode pengumpulan data dengan memberikan beberapa pertanyaan kepada para pengguna Tokopedia terkait topik yang akan diambil dalam penelitian ini yaitu digital loyalty program, kepuasan pelanggan, dan loyalitas pelanggan yang terjadi pada perusahaan Tokopedia. Penyebaran kuesioner dilakukan dengan menggunakan Electronic and Online Questionnaires melalui Google Form dan menyebarkan link tersebut kepada para pengguna Tokopedia melalui Facebook, Whatsapp, dan Telegram sebanyak sampel yang dibutuhkan.

Target populasi dalam penelitian ini adalah pengguna aplikasi Tokopedia dengan berbagai demografi. Kriteria yang akan dipakai dalam penentuan target sampel adalah (1) Pengguna aplikasi Tokopedia, (2) Pernah melakukan transaksi di Tokopedia, dan (3) Melakukan transaksi yang cukup sering melalui Tokopedia (lebih dari 5 kali transaksi). Metode sampling yang akan digunakan adalah purposive sampling yaitu sampel yang dipilih memiliki beberapa kriteria inklusi sesuai dengan 3 kriteria diatas. Sampling akan dibagikan melalui media sosial. Berdasarkan jumlah pengguna Tokopedia yang mencapai 10 juta user, jumlah minimal sample yang diperlukan adalah 384 sample (Sekaran, 2016). Besaran sample ini dianggap cukup sesuai untuk kebanyakan penelitian (Roscoe, 1975).

Statistic Parametric dengan Uji Regresi Linear Berganda digunakan dalam penelitian ini sebagai analisa statistik dengan menguji variabel bebas dan variabel mediasi terhadap variabel terikat. Sebelum melakukan uji regresi linear berganda, dilakukan beberapa pengujian terlebih dahulu seperti uji validitas dan uji reliabilitas 
untuk menguji butir-butir kuesioner yang akan digunakan. Kemudian dilakukan uji normalitas, uji linearitas, dan uji heteroskedastisitas sebagai syarat kelayakan model regresi linear. Uji parameter secara simultan atau bersamaan (uji F) dan secara individual (uji t) dilakukan untuk membuktikan adanya pengaruh atau hubungan antar variabel baik secara individual maupun secara bersamaan atau simultan. Agar diketahui sifat dari hubungan antar variabel dalam penelitian maka dilakukan uji korelasi (Riduwan\&Engkos, 2017) dengan kriteria sebagai berikut; 0.80-1.00 (Sangat Kuat), 0.60-0.79 (Kuat), 0.40-0.59 (Cukup Kuat), 0.20-0.39 (Lemah), dan 0.00-0.19 (Sangat Lemah). Baron dan Kenny (1986) mengembangkan metode kausal step untuk menguji variabel mediasi dan akan digunakan dalam penelitian ini. Terdapat beberapa langkah dalam Metode Kausal Step adalah dengan membuat beberapa persamaan regresi. Pada langkah pertama persamaan regresi variabel $X$ terhadap $Y$, kedua variabel $X$ terhadap $M$ dan ketiga variabel $X$ terhadap $Y$ dan menambahkan variabel $M$ sebagai mediasi. Keempat membuat kesimpulan mengenai pengaruh dari variabel mediasi tersebut.

Terdapat beberapa syarat atau kriteria pada tahap uji variabel M. Pertama pada persamaan I terdapat pengaruh antara variabel $X$ dengan $M$. Kedua pada persamaan II terdapat pengaruh antara variabel $\mathrm{X}$ dengan $\mathrm{Y}$. Dan ketiga pada persamaan III terdapat pengaruh antara variabel $M$ terhadap variabel $Y$. Di mana variabel $X$ dinyatakan sebagai variabel independent, variabel $M$ sebagai variabel mediasi dan variabel $Y$ sebagai variabel dependent. Pengujian dilakukan menggunakan bantuan program SPSS.

\section{C.1. Diagram Model Regresi Variabel Mediasi Dengan Metode Kausal Step}

Berikut merupakan diagram model regresi menggunakan metode kausal step:

1. Pengaruh langsung Digital Loyalty Program terhadap Kepuasan pelanggan. Dalam pengujian ini, ingin dibuktikan signifikansi masing-masing Digital Loyalty Program milik Tokopedia terhadap kepuasan pelanggan dalam berbelanja di Tokopedia.

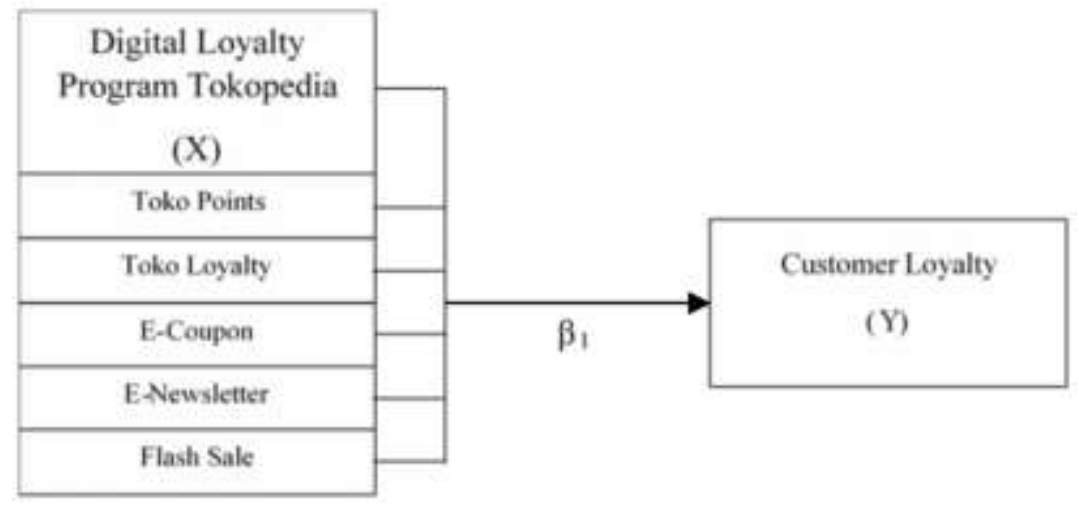

Sumber: Peneliti (2019)

Gambar 2. Pengaruh Langsung Variabel $\mathrm{X}$ terhadap Variabel $\mathrm{M}$ 
Persamaan regresi pada model pertama sebagai berikut:

$M=\beta_{0}+\beta_{1} X$

2. Pengaruh langsung Digital Loyalty Program terhadap Loyalitas pelanggan. Dalam pengujian ini, ingin dibuktikan signifikansi masing-masing Digital Loyalty Program milik Tokopedia terhadap loyalitas pelanggan dalam berbelanja di Tokopedia.

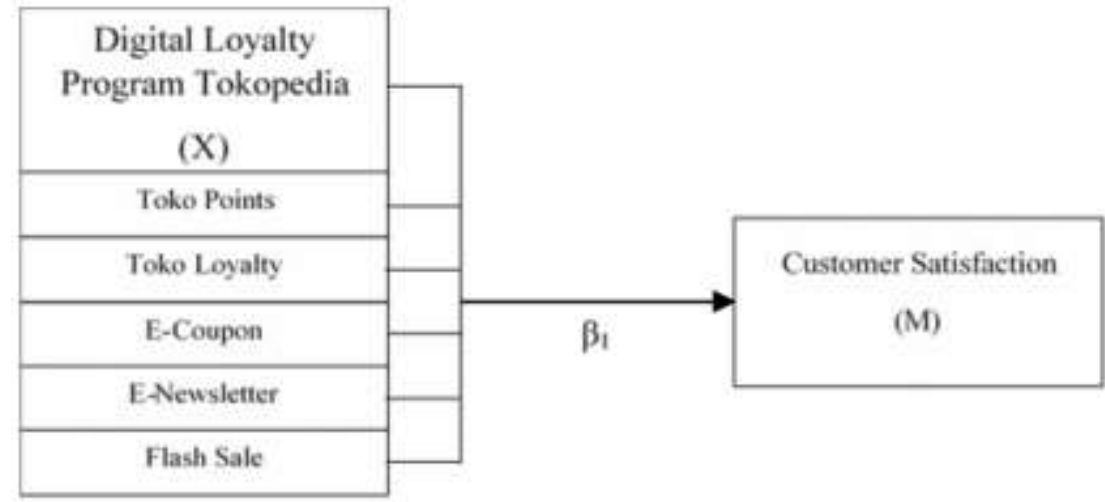

Sumber: Peneliti (2019)

Gambar 3. Pengaruh Langsung Variabel $X$ terhadap Variabel $Y$

Persamaan regresi pada model kedua sebagai berikut:

$Y=\beta_{0}+\beta_{1} X$

3. Pengaruh tidak langsung Digital Loyalty Program terhadap Loyalitas pelanggan melalui Kepuasan Pelanggan sebagai mediasi. Dalam pengujian ini, ingin dibuktikan pengaruh mediasi dari Kepuasan pelanggan terhadap signifikansi Digital Loyalty Program terhadap Loyalitas pelanggan.

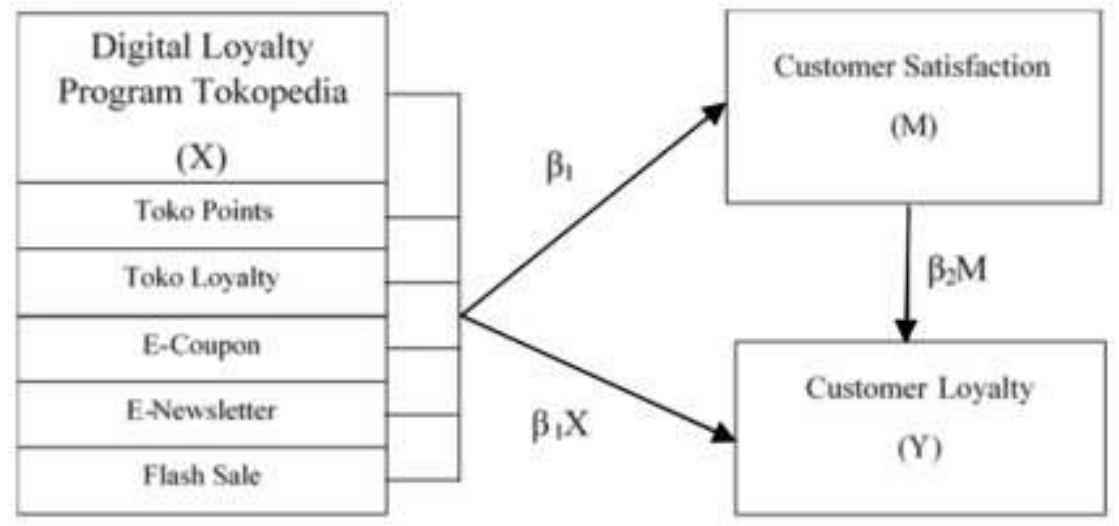

Sumber: Peneliti (2019)

Gambar 4. Pengaruh Tidak Langsung X Terhadap Y Melalui M Sebagai Mediasi 
Persamaan regresi pada model ketiga sebagai berikut:

$Y=\beta_{0}+\beta_{1} X+\beta_{2} M$

Jenis-jenis variabel mediasi adalah pertama perfect mediation jika pengaruh dari variabel $X$ dengan variabel $Y$ yang awalnya tidak signifikan menjadi signifikan setelah memasukkan variabel M. Kedua partial mediation jika pengaruh dari variabel $X$ dengan variabel $Y$ tetap signifikan meskipun telah memasukkan variabel $M$ dalam model regresinya.

\section{HASIL DAN PEMBAHASAN}

\section{D.1 Analisis Regresi Model Pertama}

Dilihat pada tabel 2, nilai Signifikansi yang dimiliki oleh seluruh item pada Variabel Digital Loyalty Program $(\mathrm{X})<0.05$ yang artinya Variabel Digital Loyalty Program (X) mempengaruhi Variabel Kepuasan pelanggan (M) baik secara individual/parsial (uji t) maupun secara bersamaan atau simultan (uji F) besarnya pengaruh tersebut dilihat dari nilai $R$-Square sebesar .822 artinya Variabel Digital Loyalty Program (X) mempengaruhi Kepuasan pelanggan (M) sebesar $82.2 \%$ dan sisanya sebesar $17.8 \%$ dipengaruhi oleh variabel lain diluar penelitian ini.

Tabel 2. Uji Regresi Model Pertama

\begin{tabular}{|l|l|l|l|l|l|l|}
\hline \multicolumn{1}{|c|}{ Variables } & $\begin{array}{c}\text { Standardized } \\
\text { Coefficient (Beta) } \\
\text { for } \\
\text { Kepuasan } \\
\text { pelanggan (M) }\end{array}$ & $\begin{array}{c}\text { Correlatio } \\
\mathbf{n} \\
\text { Pearson }\end{array}$ & t-Value & $\begin{array}{c}\text { F- } \\
\text { Value }\end{array}$ & $\begin{array}{c}\text { R- } \\
\text { Square }\end{array}$ & Sig \\
\hline Digital Loyalty & .906 & & & & & .000 \\
\hline Program & .076 & .772 & 2.683 & 97.064 & .822 & .008 \\
\hline Toko Points & .182 & .678 & 4.560 & & & .000 \\
Toko Loyalty & .250 & .757 & 3.796 & & & .000 \\
E-coupon & .232 & .717 & 3.183 & & \\
E-Newsletter & .189 & .744 & 4.557 & & & .000 \\
Flash Sale & .269 &
\end{tabular}

Sumber: Hasil olah data SPSS (2019)

Sedangkan untuk melihat besarnya pengaruh antara masing-masing Digital Loyalty Program terhadap Kepuasan pelanggan dapat dilihat pada nilai correlationpearson, dimana Toko Points memberikan pengaruh yang paling besar karena memiliki hubungan yang kuat dan searah (positif) terhadap Kepuasan pelanggan. 


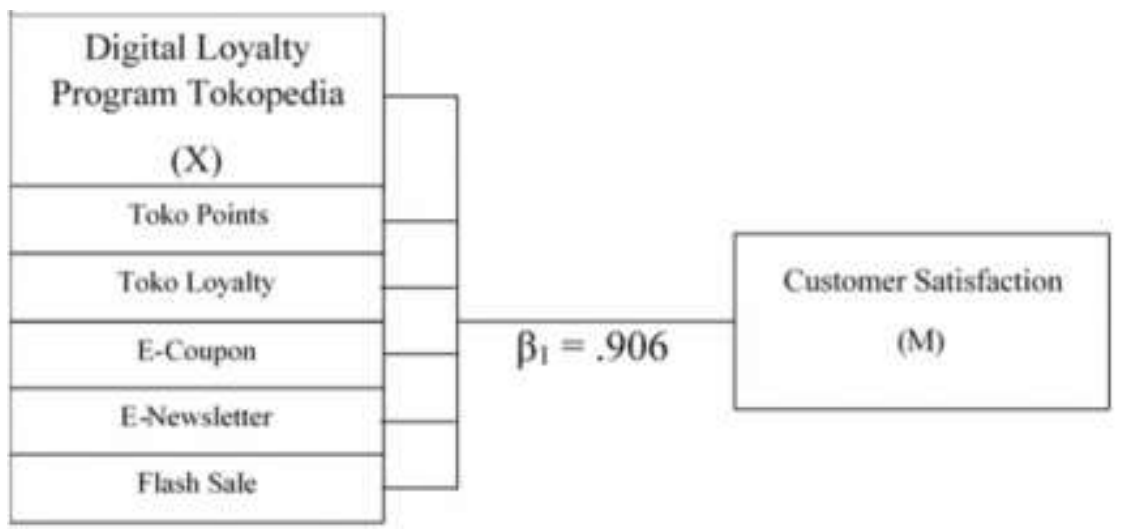

Sumber: Peneliti (2019)

Gambar 5. Pengaruh Langsung Variabel X terhadap Variabel M

Berdasarkan pengolahan data menggunakan bantuan program SPSS, Variabel Digital Loyalty Program (X) terhadap Kepuasan pelanggan (M) diperoleh nilai koefisien konstanta sebesar .076 dan nilai koefisien regresi sebesar .906 maka persamaan regresi untuk model pertama sebagai berikut:

$M=\beta_{0}+\beta_{1} X$

Kepuasan pelanggan $=.076+.906$ Digital Loyalty Program

Sehingga dapat disimpulkan bahwa kriteria pertama "variabel independent (X) berpengaruh terhadap variabel yang diduga sebagai variabel mediasi (M)" untuk menguji variabel Kepuasan pelanggan (M) sebagai variabel mediasi terpenuhi.

\section{D.2 Analisis Regresi Model Kedua}

Dilihat pada tabel 3, nilai Signifikansi yang dimiliki oleh seluruh item pada Variabel Digital Loyalty Program $(\mathrm{X})<0.05$ yang artinya Variabel Digital Loyalty Program (X) mempengaruhi Variabel Loyalitas pelanggan (Y) baik secara individual/parsial (uji t) maupun secara bersama-sama/simultan (uji F) besarnya pengaruh tersebut dapat dilihat pada nilai $R$-Square sebesar .804 artinya Variabel Digital Loyalty Program (X) mempengaruhi Loyalitas pelanggan (Y) sebesar $80.4 \%$ dan sisanya sebesar $19.6 \%$ dipengaruhi oleh variabel lain diluar penelitian ini.

Tabel 3. Uji Regresi Model Kedua

\begin{tabular}{|l|l|l|l|l|l|l|}
\hline \multicolumn{1}{|c|}{ Variables } & $\begin{array}{c}\text { Standardized } \\
\text { Coefficient (Beta) for } \\
\text { Loyalitas pelanggan (Y) }\end{array}$ & $\begin{array}{c}\text { Correlatio } \\
\mathbf{n} \\
\text { Pearson }\end{array}$ & $\begin{array}{c}\mathbf{t}- \\
\text { Value }\end{array}$ & $\begin{array}{c}\text { F- } \\
\text { Value }\end{array}$ & $\begin{array}{c}\text { R- } \\
\text { Squa } \\
\text { re }\end{array}$ & Sig \\
\hline$\frac{\text { Digital Loyalty }}{\text { Program }}$ & .896 & & & & & .000 \\
\hline$\frac{\text { Constant) }}{\text { Toko Points }}$ & .006 & & & & & \\
Toko Loyalty & .162 & .756 & 2.275 & & & .025 \\
E-coupon & .206 & .645 & 3.570 & & & .001 \\
E-Newsletter & .219 & .771 & 4.454 & 85.981 & .804 & .000 \\
Flash Sale & .232 & .724 & 3.503 & & & .001 \\
\hline
\end{tabular}

Sumber: Hasil olah data SPSS (2019) 
Sedangkan untuk mengetahui besarnya pengaruh antara masing-masing Digital Loyalty Program terhadap Loyalitas pelanggan dapat dilihat pada nilai correlation-pearson, dimana E-coupon memberikan pengaruh yang paling besar karena memiliki hubungan yang kuat dan searah (positif) terhadap Kepuasan pelanggan.

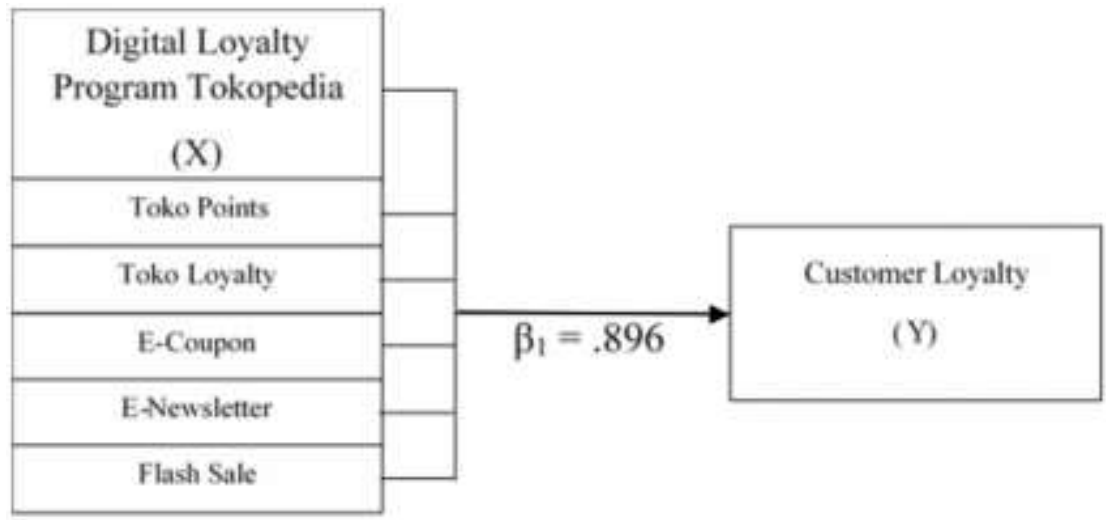

Sumber: Peneliti (2019)

Gambar 6. Pengaruh Langsung Variabel $\mathrm{X}$ terhadap Variabel $\mathrm{Y}$

Berdasarkan pengolahan data menggunakan bantuan program SPSS, Variabel Digital Loyalty Program (X) terhadap Loyalitas pelanggan (Y) diperoleh nilai koefisien konstanta sebesar .006 dan nilai koefisien regresi sebesar .896 maka persamaan regresi untuk model pertama sebagai berikut:

$M=\beta_{0}+\beta_{1} X$

Loyalitas pelanggan $=.006+.896$ Digital Loyalty Program

Sehingga dapat disimpulkan kriteria kedua "variabel independent $(\mathrm{X})$ berpengaruh terhadap variabel dependent $(\mathrm{Y})$ " untuk menguji variabel Kepuasan pelanggan (M) sebagai variabel mediasi terpenuhi.

\section{D.3. Analisis Regresi Model Ketiga}

Dilihat pada tabel 4, nilai Signifikansi yang dimiliki oleh Variabel Digital Loyalty Program $(\mathrm{X})$ dan Variabel Kepuasan pelanggan $(\mathrm{M})<0.05$.

Tabel 4. Uji Regresi Model Ketiga

\begin{tabular}{|l|l|l|l|l|l|l|}
\hline Variables & $\begin{array}{c}\text { Standardized } \\
\text { Coefficient } \\
\text { (Beta) for } \\
\text { Loyalitas } \\
\text { pelanggan (Y) }\end{array}$ & $\begin{array}{l}\text { Correlation } \\
\text { Pearson }\end{array}$ & t-Value & $\begin{array}{l}\text { F- } \\
\text { Value }\end{array}$ & $\begin{array}{l}\text { R- } \\
\text { Square }\end{array}$ & Sig \\
\hline (Constant) & -.044 & & & & & \\
\hline $\begin{array}{l}\text { Digital Loyalty } \\
\text { Program }\end{array}$ & .322 & .896 & 4.015 & 378.60 & .875 & .000 \\
\hline Kepuasan pelanggan & .634 & .925 & 7.904 & 0 & .000 \\
\hline
\end{tabular}

Sumber: Hasil olah data SPSS (2019) 
Hal tersebut menunjukan bahwa Variabel Digital Loyalty Program (X) dan Variabel Kepuasan pelanggan $(\mathrm{Y})$ mempengaruhi Variabel Loyalitas pelanggan $(\mathrm{Y})$ secara individual dan simultan serta besarnya pengaruh tersebut dilihat dari nilai $R$ Square sebesar .875 artinya Variabel Digital Loyalty Program (X) dan Variabel Kepuasan pelanggan (M) mempengaruhi Loyalitas pelanggan ( $\mathrm{Y}$ ) sebesar $87.5 \%$ dan sisanya dipengaruhi oleh variabel lain yang tidak ada dalam penelitian ini.

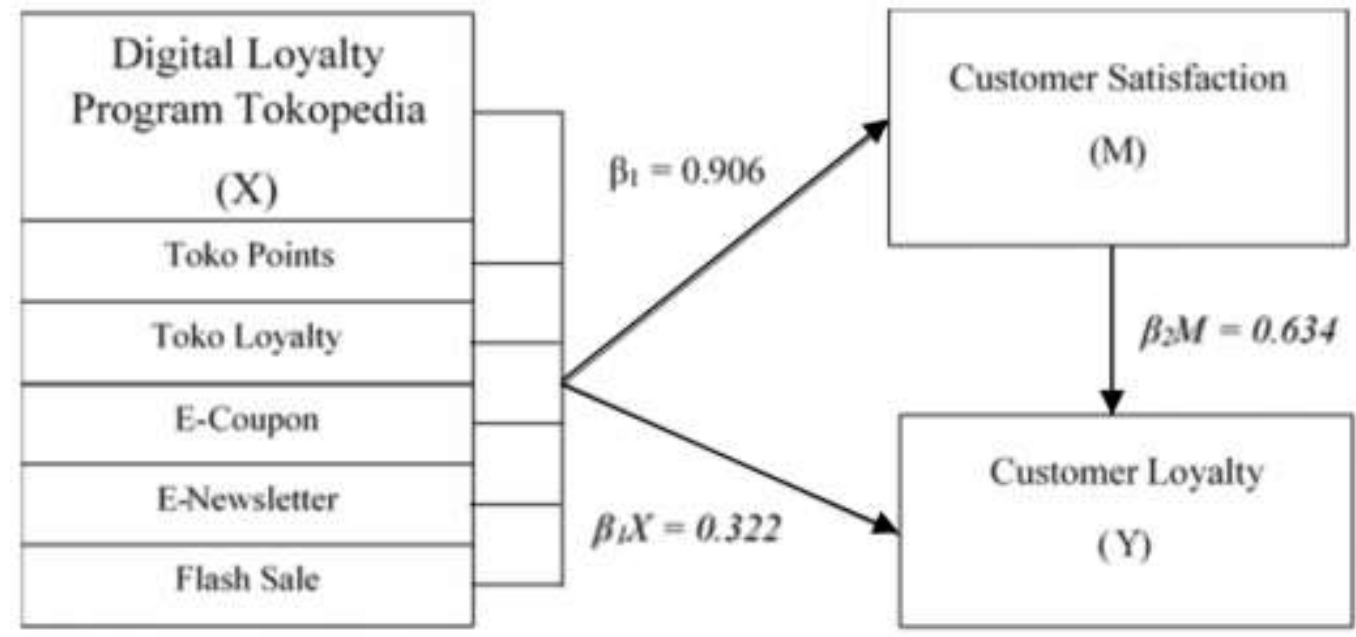

Sumber: Peneliti (2019)

Gambar 7. Pengaruh Tidak Langsung X Terhadap Y Melalui M Sebagai Mediasi

Berdasarkan pengolahan data menggunakan bantuan program SPSS, Variabel Digital Loyalty Program (X) terhadap Loyalitas pelanggan (Y) diperoleh nilai koefisien konstanta sebesar -.044 dan nilai koefisien regresi Variabel Digital Loyalty Program (X) sebesar .322 dan nilai koefisien regresi Variabel Kepuasan pelanggan (M) sebesar .634 maka persamaan regresi untuk model pertama sebagai berikut:

$Y=\beta_{0}+\beta_{1} X+\beta_{2} M$

Loyalitas pelanggan $=-.044+.322$ Digital Loyalty Program +.634 Kepuasan pelanggan

Sehingga dapat disimpulkan dari beberapa keputusan diatas, diketahui nilai standardized coefficients beta yang diperoleh variabel Digital Loyalty Program (X) melemah atau menurun $0.322<0.896$ dengan adanya penambahan Variabel Kepuasan pelanggan (M) yang artinya Variabel Kepuasan pelanggan (M) disini memiliki peran mediasi terhadap Variabel Digital Loyalty Program $(\mathrm{X})$ dan Loyalitas pelanggan $(\mathrm{Y})$, selain itu kriteria ketiga untuk menguji variabel Kepuasan pelanggan (M) sebagai variabel mediasi terpenuhi. 


\section{D.4. Pengujian Hipotesis}

Tabel dibawah ini menunjukan hasil dari tiap pengujian hipotesis.

Tabel 5. Pengujian Hipotesis

\begin{tabular}{|c|c|c|}
\hline Hipotesis & Hasil & \\
\hline $\begin{array}{l}\text { H1 Digital Loyalty programs } \\
\text { significantly influence } \\
\text { kepuasan pelanggan }\end{array}$ & $\beta=.906$, Sig $=.000<0.05$ & $\begin{array}{l}\text { Variabel Digital Loyalty Program } \\
(\mathrm{X}) \text { berpengaruh secara } \\
\text { signifikan terhadap Variabel } \\
\text { Kepuasan pelanggan (M). }\end{array}$ \\
\hline $\begin{array}{l}\text { H1a Toko Points prog } \\
\text { significantly influ } \\
\text { kepuasan pelanggan }\end{array}$ & $\beta=.182$, Sig $=.008<0.05$ & $\begin{array}{llr}\text { Toko } & \text { Points } & \text { berpengaruh } \\
\text { secara } & \text { signifikan terhadap } \\
\text { Variabel } & \text { Kepuasan pelanggan } \\
\text { (M). } & \end{array}$ \\
\hline $\begin{array}{l}\text { H1b Toko Loyalty prog } \\
\text { significantly influ } \\
\text { kepuasan pelanggan }\end{array}$ & $=.250$, Sig $=.000<0.05$ & $\begin{array}{llr}\text { Toko Loyalty } & \text { berpengaruh } \\
\text { secara } & \text { signifikan terhadap } \\
\text { Variabel } & \text { Kepuasan pelanggan } \\
\text { (M). } & \end{array}$ \\
\hline $\begin{array}{l}\text { H1c E-coupon programs } \\
\text { significantly influence } \\
\text { kepuasan pelanggan }\end{array}$ & $\beta=.232$, Sig $=.000<0.05$ & $\begin{array}{l}\text { E-coupon berpengaruh secara } \\
\text { signifikan terhadap Variabel } \\
\text { Kepuasan pelanggan (M). }\end{array}$ \\
\hline $\begin{array}{l}\text { H1d E-newsletter programs } \\
\text { significantly influence } \\
\text { kepuasan pelanggan }\end{array}$ & $\beta=.189$, Sig $=.002<0.05$ & $\begin{array}{l}\text { E-Newsletter berpengaruh } \\
\text { secara signifikan terhadap } \\
\text { Variabel Kepuasan pelanggan } \\
\text { (M). }\end{array}$ \\
\hline $\begin{array}{l}\text { H1e Flash Sale pros } \\
\text { significantly infl } \\
\text { kepuasan pelanggan }\end{array}$ & $\beta=.269$, Sig $=.000<0.05$ & $\begin{array}{l}\text { Flash Sale berpengaruh } \mathrm{s} \epsilon \\
\text { signifikan terhadap Var } \\
\text { Kepuasan pelanggan (M). }\end{array}$ \\
\hline $\begin{array}{l}\mathrm{H} 2 \text { Digital Loyalty programs } \\
\text { significantly influence } \\
\text { loyalitas pelanggan }\end{array}$ & $\beta=.896$, Sig $=.000<0.05$ & $\begin{array}{l}\text { Variabel Digital Loyalty Program } \\
(\mathrm{X}) \text { berpengaruh secara } \\
\text { signifikan terhadap Variabel } \\
\text { Loyalitas pelanggan }(\mathrm{Y}) \text {. }\end{array}$ \\
\hline $\begin{array}{l}\text { H2a Toko Points prog } \\
\text { significantly influ } \\
\text { loyalitas pelanggan }\end{array}$ & $\beta=.162$, Sig $=.025<0.05$ & $\begin{array}{llr}\text { Toko Points } & \text { berpengaruh } \\
\text { secara } & \text { signifikan } & \text { terhadap } \\
\text { Variabel } & \text { Loyalitas pelanggan } \\
\text { (Y). } & & \end{array}$ \\
\hline $\begin{array}{l}\text { H2b Toko Loyalty programs } \\
\text { significantly influence } \\
\text { loyalitas pelanggan }\end{array}$ & $\beta=.206$, Sig $=.001<0.05$ & $\begin{array}{lrr}\text { Toko } & \text { Loyalty } & \text { berpengaruh } \\
\text { secara } & \text { signifikan } & \text { terhadap } \\
\text { Variabel } & \text { Loyalitas } & \text { pelanggan } \\
\text { (Y). } & & \end{array}$ \\
\hline $\begin{array}{l}\text { H2C E-coupon programs } \\
\text { significantly influence } \\
\text { loyalitas pelanggan }\end{array}$ & $\beta=.287$, Sig $=.000<0.05$ & $\begin{array}{l}\text { E-coupon berpengaruh secara } \\
\text { signifikan terhadap Variabel } \\
\text { Loyalitas pelanggan }(\mathrm{Y}) \text {. }\end{array}$ \\
\hline $\begin{array}{l}\mathrm{H} 2 \mathrm{~d} \text { E-newsletter programs } \\
\text { significantly influence } \\
\text { loyalitas pelanggan }\end{array}$ & $\beta=.219$, Sig $=.000<0.01$ & $\begin{array}{l}\text { E-Newsletter berpengaruh } \\
\text { secara signifikan terhadap } \\
\text { Variabel Loyalitas pelanggan } \\
\text { (Y). }\end{array}$ \\
\hline $\begin{array}{l}\mathrm{H} 2 \mathrm{e} \text { Flash Sale progr } \\
\text { significantly }\end{array}$ & $\beta=.232$, Sig $=.000<0.05$ & $\begin{array}{l}\text { Flash Sale berpengaruh secara } \\
\text { signifikan terhadap Variabel }\end{array}$ \\
\hline
\end{tabular}




\begin{tabular}{|c|c|c|}
\hline loyalitas pelanggan & & Loyalitas pelanggan (Y). \\
\hline $\begin{array}{l}\text { H3 Kepuasan pelanggan } \\
\text { significantly influence } \\
\text { loyalitas pelanggan }\end{array}$ & $\beta=.634$, Sig $=.000<0.05$ & $\begin{array}{l}\text { Variabel Kepuasan pelanggan } \\
(\mathrm{M}) \text { berpengaruh secara } \\
\text { signifikan terhadap Variabel } \\
\text { Loyalitas pelanggan }(\mathrm{Y}) \text {. }\end{array}$ \\
\hline $\begin{array}{l}\mathrm{H} 4 \text { Kepuasan pelanggan } \\
\text { mediates the relationship } \\
\text { between loyalty programs } \\
\text { and loyalitas pelanggan }\end{array}$ & \begin{tabular}{lrr} 
Nilai & \multicolumn{2}{c}{ standardized } \\
coefficients & beta & yang \\
diperoleh & variabel & Digital \\
Loyalty & Program $\quad(\mathrm{X})$ \\
melemah & atau & menurun \\
0.322 & $<$ & 0.896 dengan \\
adanya & \multicolumn{2}{c}{ penambahan } \\
Variabel & \multicolumn{2}{c}{ Kepuasan } \\
pelanggan (M) & &
\end{tabular} & $\begin{array}{l}\text { Variabel Kepuasan pelanggan } \\
(\mathrm{M}) \text { memiliki peran mediasi } \\
\text { terhadap Variabel Digital Loyalty } \\
\text { Program (X) dan Loyalitas } \\
\text { pelanggan (Y), selain itu seluruh } \\
\text { kriteria sebagai syarat pengujian } \\
\text { variabel mediasi dalam } \\
\text { penelitian ini telah terpenuhi. }\end{array}$ \\
\hline
\end{tabular}

Sumber: Peneliti (2019)

\section{E. KESIMPULAN}

Dari hasil analisa yang telah dibahas sebelumnya, penting untuk dilihat bahwa Variabel Digital Loyalty Program (beserta seluruh Loyalty Program Tokopedia) berpengaruh pada Kepuasan pelanggan dan Loyalitas pelanggan Tokopedia. Digital Loyalty Program yang memiliki pengaruh paling besar terhadap Kepuasan pelanggan adalah Toko Points dan program yang berpengaruh paling besar terhadap Loyalitas pelanggan adalah E-coupon. Hasil tersebut diduga karena Toko Points memberikan keuntungan kepada pengguna Tokopedia dengan menukarkan poin untuk mendapatkan kupon-kupon menarik seperti Cashback, gratis ongkos kirim, dan discount lainnya sehingga membuat pelanggan Tokopedia merasa puas dengan keuntungan yang didapatkan hingga akhirnya loyal terhadap Tokopedia. Variabel Kepuasan pelanggan pada penelitian ini juga berperan sebagai Variabel Mediasi yang menjelaskan bahwa Variabel Digital Loyalty Program berpengaruh terhadap Variabel Loyalitas pelanggan secara tidak langsung melalui Kepuasan pelanggan Tokopedia.

Pengaruh dari kepuasan terhadap loyalitas pelanggan telah dibuktikan oleh penelitian Iddrisua et al (2015) yang menyatakan bahwa adanya pengaruh secara langsung antar variabel tersebut, penelitian ini akan berfokus pada bagaimana pengaruh dari Digital Loyalty Program terhadap kepuasan pelanggan dan loyalitas pelanggan. Para pengunjung sekaligus pelanggan terbukti loyal terhadap website Tokopedia dilihat dari hasil dan perhitungan data pada Visitor Loyalty yang menunjukkan peningkatan yang cukup drastis. Hal ini mendapat persamaan dengan penelitian sekarang bahwa variabel-variabel yang diteliti terdapat hubungan yang saling berpengaruh satu dengan yang lain. Dari penelitian yang didapat. Pihak manajemen dapat mengambil langkah-langkah untuk tetap melakukan promosi yang sekarang ada, memperbaiki atau melihat promosi maupun program yang kurang efisien dalam menarik perhatian pelanggan. 


\section{DAFTAR PUSTAKA}

Akbar, R.J. (2018). 10 Marketplace Terpopuler di Indonesia Kuartal I 2019. Retrieved from https://www.viva.co.id/berita/bisnis/1147950-10-marketplace-terpopuler-di indonesia-kuartal-i-2019-siapa-juaranya

Anjungroso, F. (2018). Nilai Tokopedia Disebut-sebut sudah Tembus Rp 102 Triliun. Retrieved from https://www.tribunnews.com/techno/2018/11/22/nilai-tokopedia disebut-sebut-sudah-tembus-rp-102-triliun

Sutarman, A., \& Lesmana, R. (2019, January). Analisis Keputusan Pembelian Konsumen dari Sisi Normtif dan Informatif Pada Supermarket Giant Pamulang, Tangerang Selatan. In PROCEEDINGS (Vol. 1, No. 1).

A.M. Iddrisua, I.K. Noonib, Fiankoc, K.S., W. Mensahd. (2015). Assessing the impact of

service quality on customer loyalty: a case study of the cellular industry of Ghana. British Journal of Marketing Studies Vol.3, No.6.

Bolton, R. N., Kannan, P. K., \& Bramlett, M. D. (2000). Implications of loyalty program membership and service experiences for customer retention and value. Journal of the Academy of Marketing Science Vol.28(1), 95-108. https://doi.org/DOI $\underline{10.1177 / 0092070300281009}$

Breugelmans, Els. (2014). Advancing Research on Loyalty Programs: A Future Research Agenda. New York: Springer Science Business Media

Buttle, Francis. (2004). Customer Relationship Management (Management Hubungan Pelanggan) Concept and Tools. (diterjemahkan oleh Arief Subianto)

Bayumedia: Malang.

Chen, James. (2017). Loyalty Program. Retrieved from https://www.investopedia.com/terms///loyaltyprogram.asp

Dowling, G.R. \& Uncles, M. (1997). Do customer loyalty programs really work?. Sloan Management Review Vol.38, No. 4, pp.71-82

E-satisfaction. 8 Types of customer loyalty program. Retrieved from https://www.e satisfaction.com/8-types-of-customer-loyalty-programs/

Helena, Nobre. (2018). Loyalty programs in the pharmaceutical retail: The impact of a network loyalty program on the pharmacy loyalty. International Journal of Business Excellence Vol. 14, No. 4, 2018. https://doi.org/10.1504/ijbex.2018.090312

Kooser, A. C. (2009). Online Loyalty Programs. Restaurant Business, 108 (11): 18. 
Kotler, Philip. \& Gary Armstrong. (2014). Principle of Marketing, 15th edition. New Jersey: Pearson Prentice Hall.

Kotler, Philip \& Keller, K.L. (2016). Marketing Management. 15th Global Edition. England: Pearson Education.

Leenheer, J., van Heerde, H.J., Bijmolt, T.H.A. and Smidts, A. (2007). 'Do loyalty programs reallyenhance behavioral loyalty? An empirical analysis accounting for self-selectingmembers'. International Journal of Research in Marketing Vol. 24, No. 1, pp.31-47. https://doi.org/10.1016/j.jiresmar.2006.10.005

Loyalty corp. Digital rewards platforms vs Physical Rewards Programs. Retrieved from https://loyaltycorp.com.au/digital-rewards-programs-vs-physical-rewardsprograms/

Meyer-Waarden, L. (2008). The influence of loyalty programs membership on customer

purchase behavior. European Journal of Marketing Vol. 42(1). https://doi.org/10.1108/03090560810840925

Munawaroh., Desi Yuniarti., Memi Nor Hayati. (2015). Mediation Regression Analysis with Causal Step Method (Case Study: Product Domestic Regional Bruto (PDRB) Per Capita inEast Kalimantan Timur in Year 2011-2013). Jurnal Eksponensial Vol. 6, No.2

Parahoo, S.K. (2013). 'Role of involvement and commitment insustaining firmcustomer relationships: an empirical investigation'. International Journal of Procurement Management Vol. 6, No.4, pp.407-423. https://doi.org/10.1504/ijpm.2013.054751

Lesmana, R., \& Hasbiyah, W. (2019). Model Analisis Kepuasan dan Loyalitas Wisatawan Lokal Studi Kasus pada Objek Wisata Kepulauan Seribu Jakarta. JIMF (Jurnal IImiah Manajemen Forkamma), 2(3).

Lesmana, R. (2019). Pengaruh Kualitas Produk Dan Kualitas Pelayanan Terhadap Kepuasan Konsumen Pt. Radekatama Piranti Nusa. Jurnal Pemasaran Kompetitif, 2(2), 115-129.

Lesmana, R. (2015). analisis strategi pemasaran untuk meningkatkan penjualan perumahan green river city bekasi (study kasus di pt. artha bangun pratama) (Doctoral dissertation, Universitas Pamulang).

Sari, H.K. (2009). Efektivitas Loyalty Program dalam Customer Relationship Management terhadap Kepuasan dan Loyalitas Pelanggan. Jurnal IImu Komunikasi Vol. 6, No. 2. https://doi.org/10.24002/jik.v6i2.202

Sekaran, Uma \& Roger Bougie. (2016). Research Methods for Business, Seventh Edition. Chichester Wesr Sussex; United Kingdom. 
Sharp, Byron; Sharp, Anne. (1997). "Loyalty Programs and their Impact on Repeatpurchase Loyalty Patterns". International Journal of Research in Marketing Vol 14, No. 5, p.473 486. https://doi.org/10.1016/s0167-8116(97)00022-0

Sunardi, N., Lesmana, R., Tumanggor, M., \& Kadim, A. (2019). Implementasi IImu Manajemen dalam Mewujudkan Pembangunan Masjid Raya Abdul Kadim, Yayasan Ar-Rohim, Kab. Musi Banyuasin, Propinsi Sumatra Selatan. Jurnal Abdi Masyarakat Humanis, 1(1).

Simorangkir, Eduardo (2018). Peran e-commerce Dorong Percepatan Pertumbuhan Ekonomi Kreatif. Retrieved from https://finance.detik.com/berita-ekonomibisnis/d4294602/peran-e-commerce-dorong-percepatan-pertumbuhan-ekonomi-kreatif

Soderfund, M \& Colliander, J. (2015). Loyalty program rewards and their impacts on perceived justice,customer satisfaction and repatronize intentions. Journal of Retailing and Consumer Services Vol.25 pp.47-57. https://doi.org/10.1016/.j.jretconser.2015.03.005

Stathopoulou, A \& Balabanis, G. (2016). The effect of loyalty programs on kepuasan pelanggan, trust, and loyalty toward high and low-end fashin retailer. Journal of Business Research Vol.69 Issue 12 pp.5801-5808. https://doi.org/10.1016/j.jbusres.2016.04.177

Abba Sungirirai, Douglas Chiguvi, Loyd Sungirirai. (2017) "The Effect of Customer Loyalty Programs on Customer Satisfaction in the Mobile Telecommunications Sector in Botswana". International Journal of Science and Research (IJSR) $\begin{array}{llllll}\text { Volume } 6 & 6 & \text { Issue } & 2, & \text { pp.1815 } & -\end{array}$ https://www.ijsr.net/search index results paperid.php?id=ART20164139

Tahal, R. (2014). Loyalty Programs in E-Commerce and Their Perception By The Young Adult Internet Population. Central European Business Review Vol.3 Issue 2 pp. 7-13. https://doi.org/10.18267/j.cebr.79

Tjiptono, Fandy., dan Gregorius Chandra. (2016). Service, Quality Satisfaction, Edisi 4. Yogyakarta: Andi Offset.

Vesel, P \& Zabkar, V. (2009). Managing Customer Loyalty Through the Mediating Role of Satisfaction in the DIY Retail Loyalty Program. Journal of Retailing and Consumer Services Vol.16 Issue 5 pp. 396-406. https://doi.org/10.1016/.j.jretconser.2009.05.002

Waari, D., Bonuke, R \& Kosgei, G. (2018). Loyalty Programs Benefits and Customer Loyalty: The Mediating Role Of Customer Satisfaction. International Journal of Economics, Commerce and Management Vol. VI Issue 4.

Zakaria, I., Rahman, B.Ab., Othman, A.K., Yunus, N.A.M., Dzulkipli, M.R., Osman, M.A.F. (2015). The Relationship between Loyalty Program, Customer Satisfaction, and Customer Loyalty in Retail Industry: A Case Study. Procedia Social and Behavioral Sciences Vol. 129 pp. 23-30. https://doi.org/10.1016/j.sbspro.2014.03.643 